\title{
PROFILAKTINIŲ SKIEPIJIMŲ TYMU, RAUDONUKĖS IR EPIDEMINIO PAROTITO VAKCINA APRĖPTIES APŽVALGA LIETUVOS SAVIVALDYBĖSE 2010-2018 METAIS
}

\author{
Gabrielia Malgožata Gulbinovič ${ }^{1}$, Nerija Kuprevičienè ${ }^{2}$ \\ ${ }^{I}$ Nacionalinio visuomenès sveikatos centro prie Sveikatos apsaugos ministerijos \\ Vilniaus departamentas, ${ }^{2}$ Vilniaus universiteto Medicinos fakulteto Sveikatos moksly instituto \\ Visuomenès sveikatos katedra
}

Raktažodžiai: profilaktiniai skiepijimai, profilaktinių skiepijimų kalendorius, profilaktinių skiepijimų aprèptis, tymų, raudonukès ir epideminio parotito vakcina, MMR vakcina.

\section{Santrauka}

Nepakankama profilaktinių skiepijimų aprèptis gali lemti užkrečiamujų ligų, tarp jų ir visuomenès pamirštų bei retesnių, protrūkius. Skiepijimų aprèpties stebėsena teikia galimybę sustiprinti vakcinomis valdomų infekcinių ligų epidemiologinę priežiūrą ir kontrolę.

Tikslas - įvertinti profilaktinių skiepijimų nuo tymų, raudonukès ir epideminio parotito apréptị Lietuvos savivaldybèse 2010-2018 metais.

Metodai. Atlikta Užkrečiamųjų ligų ir AIDS centro profilaktinių skiepijimų aprépties 2010-2018 metais duomenų analizè ir aprašomasis tyrimas. Naudota WinPepi 11.65 programa, $\mathrm{R}$ programos 3.2.2 paketas. Statistiniam reikšmingumui vertinti pasirinktas Mantel-Haenszel chi kvadrato $\left(\chi^{2}\right)$ testas. Reikšmingumo lygmuo $\mathrm{p} \leq 0,05$.

Rezultatai. Daugumoje savivaldybių nustatyta vaikų skiepijimo aprèpties pirmaja bei antraja vakcinos nuo tymų, raudonukès ir epideminio parotito doze mažejjimo tendencija.

Išvados. Skiepijimo aprèpties kitimo tendencijos savivaldybèse yra skirtingos. Nevienodas asmens ir visuomenès sveikatos priežiūros specialistų požiūris, jų darbo organizavimas skirtingose teritorijose gali būti laikomas skiepijimo aprèpties netolygumų prielaida.

\section{Ivadas}

Vakcinos nuo užkrečiamụjų ligų, šimtmečiais kèlusių grèsmę žmonijai, laikomos viena iš ekonomiškai efektyviausių sveikatos intervencijų [1]. Siekiant užkirsti kelią užkrečiamosioms ligoms, svarbu palaikyti tinkamą skiepijimų aprèpti - tokiu būdu užtikrinama ne tik individo apsauga, tačiau ir kolektyvinio imuniteto, priklausančio nuo ilgalaikio palankumo skiepams, formavimasis [2-4]. Be to, vakcinų kuriama apsauga prisideda prie antibiotikų vartojimo mažinimo bei mikroorganizmų atsparumo antimikrobiniams preparatams mažejimo [5]. Skiepai sumažino užkrečiamujų ligų riziką, tačiau radosi kita, su vakcinomis siejama rizika [6]. Mažèja pasitikèjimas skiepų nauda bei jų saugumu, o tai gali sukelti skiepijimų aprèpties mažejjimą, lemsiantị infekcinių ligų protrūkius [5]. Europos Sajungos ir Europos regiono šalių patirtis rodo, kad ir nedidelis skiepijimų aprèpties svyravimas ilgainiui lemia didžiulius tarpvalstybinius užkrečiamujjų ligų protrūkius, pavyzdžiui, ilgai trunkantis tymų protrūkis Europos regione [7]. Nacionaline imunopro-

1 lentelè. Skiepijimo MMR1 vakcina aprèpties 2010-2018 metais analizė Lietuvos savivaldybèse $(\mathrm{n}=60)$

\begin{tabular}{|c|c|c|c|c|c|}
\hline \multirow{2}{*}{$\begin{array}{c}\text { Rekomenduojama } \\
\text { skiepijimo } \\
\text { aprèptis (\%) }\end{array}$} & \multicolumn{2}{|c|}{$\begin{array}{c}\text { Savivaldybių skaičius (abs. sk.), } \\
\text { nustatymo metai }\end{array}$} & \multirow{2}{*}{$\begin{array}{c}\text { Metinis } \\
\text { vidutinis } \\
\text { pokytis (\%) }\end{array}$} & \multirow{2}{*}{$95 \%$ PI } & \multirow{2}{*}{$\begin{array}{c}\text { M-H } \\
\mathbf{p}\end{array}$} \\
\hline & mažiausias & didžiausias & & & \\
\hline$\leq 89,99$ & $3(2010)$ & $13(2013)$ & $+2,12$ & $-11,14 ;+17,36$ & 0,690 \\
\hline$\geq 90$ & $14(2010)$ & $30(2017)$ & $+3,25$ & $-2,08 ;+8,88$ & 0,204 \\
\hline$\geq 95$ & $24(2012)$ & $43(2010)$ & $-2,10$ & $-6,74 ;+2,77$ & 0,134 \\
\hline
\end{tabular}

2 lentelè. Skiepijimo MMR2 vakcina aprèpties 2010-2018 metais analizė Lietuvos savivaldybèse $(\mathrm{n}=60)^{*}$

* 2010 m. ir 2011 m. nagrineti 59 savivaldybiu duomenys

\begin{tabular}{|c|c|c|c|c|c|}
\hline \multirow{2}{*}{$\begin{array}{c}\text { Rekomenduojama } \\
\text { skiepijimo } \\
\text { aprèptis (\%) }\end{array}$} & \multicolumn{2}{|c|}{$\begin{array}{c}\text { Savivaldybių skaičius (abs. sk.), } \\
\text { nustatymo metai }\end{array}$} & \multirow{2}{*}{$\begin{array}{c}\text { Metinis } \\
\text { vidutinis } \\
\text { pokytis (\%) }\end{array}$} & \multirow[t]{2}{*}{$95 \%$ PI } & \multirow{2}{*}{$\begin{array}{c}\mathbf{M}-\mathbf{H} \\
\mathbf{p} \\
\end{array}$} \\
\hline & mažiausias & didžiausias & & & \\
\hline$\leq 89,99$ & $0(2011)$ & $6(2014)$ & $+23,53$ & $\begin{array}{l}-28,58 \\
+113,66\end{array}$ & 0,749 \\
\hline$\geq 90$ & $5(2010)$ & $17(2018)$ & $+10,94$ & $+4,62 ;+17,64$ & 0,008 \\
\hline$\geq 95$ & $39(2014)$ & $50(2010)$ & $-2,19$ & $-3,86 ;-0,49$ & 0,023 \\
\hline
\end{tabular}


filaktikos 2019-2023 metų programa siekiama išlaikyti rekomenduojamą skiepijimo aprèptị (tymų ir raudonukès - ne mažiau nei 95 proc.) ne tik visoje šalyje, tačiau ir kiekvienoje savivaldybejje. Viena iš minètos programos priemonių, skirtu sustiprinti skiepais valdomų infekcinių ligų epidemiologinę priežiūrą bei skiepijimo aprèpties stebėseną, yra skiepijimo aprèpties analizė [5].

\section{Darbo tikslas}

Ivertinti profilaktiniu skiepijimų nuo tymu, raudonukès ir epideminio parotito aprèptị Lietuvos savivaldybėse 20102018 metais.

\section{Tyrimo metodai}

Tyrimui naudoti Užkrečiamujų ligų ir AIDS centro duomenys. Jų pagrindu nagrinèta 2 metų vaikų profilaktinių skiepijimų pirmaja (toliau - MMR1) ir 8 metų vaikų profilaktinių skiepijimų antraja (toliau - MMR2) vakcinos nuo

3 lentelè. Skiepijimo MMR1 vakcina aprèpties analizė Vilniaus, Kauno, Klaipėdos, Šiaulių ir Panevėžio apskričių savivaldybėse 2010-2018 metais*

* Prienu r. sav. ir Birštono sav. - 2013-2018 metais

\begin{tabular}{|c|c|c|c|c|c|}
\hline \multirow[t]{2}{*}{ Savivaldybe் } & \multicolumn{2}{|c|}{$\begin{array}{c}\text { Skiepijimo } \\
\text { aprèptis (\%), } \\
\text { jos nustatymo } \\
\text { metai }\end{array}$} & \multirow{2}{*}{$\begin{array}{c}\text { Metinis } \\
\text { vidutinis } \\
\text { pokytis } \\
(\%)\end{array}$} & \multirow[t]{2}{*}{$95 \%$ PI } & \multirow[t]{2}{*}{$\begin{array}{c}\text { M-H } \\
\text { p }\end{array}$} \\
\hline & $\begin{array}{c}\text { žemiau- } \\
\text { sia } \\
\end{array}$ & $\begin{array}{c}\text { aukš- } \\
\text { čiausia }\end{array}$ & & & \\
\hline Vilniaus m. sav. & $\begin{array}{l}91,25 \\
(2011)\end{array}$ & $\begin{array}{l}95,31 \\
(2010)\end{array}$ & $-0,11$ & $-0,44 ;+0,21$ & 0,014 \\
\hline Vilniaus r. sav. & $\begin{array}{c}92,92 \\
(2018)\end{array}$ & $\begin{array}{c}96,71 \\
(2015)\end{array}$ & $-0,17$ & $-0,46 ;+0,13$ & 0,065 \\
\hline $\begin{array}{l}\text { Trakų r. sav. ir } \\
\text { Elektrėnų sav. }\end{array}$ & $\begin{array}{c}88,79 \\
(2014) \\
\end{array}$ & $\begin{array}{c}94,13 \\
(2012) \\
\end{array}$ & $-0,06$ & $-0,56 ;+0,44$ & 0,718 \\
\hline Šalčininkų r. sav. & $\begin{array}{c}92,23 \\
(2016)\end{array}$ & $\begin{array}{l}98,75 \\
(2013)\end{array}$ & $-0,73$ & $-1,14 ;-0,32$ & $<0,001$ \\
\hline Švenčionių r. sav. & $\begin{array}{l}93,02 \\
(2011)\end{array}$ & $\begin{array}{l}97,65 \\
(2015)\end{array}$ & $+0,29$ & $-0,12 ;+0,69$ & 0,164 \\
\hline Ukmergès r. sav. & $\begin{array}{l}94,83 \\
(2017)\end{array}$ & $\begin{array}{c}97,44 \\
(2010)\end{array}$ & $-0,22$ & $-0,41 ;-0,03$ & 0,110 \\
\hline Širvintų r. sav. & $\begin{array}{r}87,32 \\
(2010) \\
\end{array}$ & $\begin{array}{l}96,75 \\
(2014) \\
\end{array}$ & $+0,30$ & $-0,55 ;+1,16$ & 0,369 \\
\hline Kauno m. sav. & $\begin{array}{c}89,43 \\
(2018) \\
\end{array}$ & $\begin{array}{c}95,44 \\
(2010) \\
\end{array}$ & $-0,75$ & $-0,89 ;-0,61$ & $<0,001$ \\
\hline Kauno r. sav. & $\begin{array}{l}90,42 \\
(2018)\end{array}$ & $\begin{array}{c}97,98 \\
(2010)\end{array}$ & $-0,74$ & $-1,05 ;-0,42$ & $<0,001$ \\
\hline Raseinių r. sav. & $\begin{array}{c}89,86 \\
(2017) \\
\end{array}$ & $\begin{array}{l}95,08 \\
(2016) \\
\end{array}$ & $-0,09$ & $-0,60 ;+0,42$ & 0,668 \\
\hline Kaišiadorių r. sav. & $\begin{array}{c}87,33 \\
(2012) \\
\end{array}$ & $\begin{array}{c}99,58 \\
(2013) \\
\end{array}$ & $-0,56$ & $-1,72 ;+0,62$ & 0,006 \\
\hline Kèdainių r. sav. & $\begin{array}{c}92,20 \\
(2018)\end{array}$ & $\begin{array}{c}96,61 \\
(2014)\end{array}$ & $-0,07$ & $-0,42 ;+0,27$ & 0,675 \\
\hline Prienų r. sav. * & $\begin{array}{l}87,76 \\
(2018) \\
\end{array}$ & $\begin{array}{l}92,22 \\
(2013)\end{array}$ & $-0,86$ & $-1,63 ;-0,09$ & 0,082 \\
\hline Jonavos r. sav. & $\begin{array}{c}84,20 \\
(2018) \\
\end{array}$ & $\begin{array}{c}98,69 \\
(2010) \\
\end{array}$ & $-1,05$ & $-2,13 ;+0,03$ & $<0,001$ \\
\hline Birštono sav. * & $\begin{array}{c}77,78 \\
(2014) \\
\end{array}$ & $\begin{array}{c}92,86 \\
(2017)\end{array}$ & $+1,23$ & $-2,05 ;+4,62$ & 0,696 \\
\hline $\begin{array}{l}\text { Klaipedos m. sav. ir } \\
\text { Neringos sav. }\end{array}$ & $\begin{array}{c}88,24 \\
(2018) \\
\end{array}$ & $\begin{array}{c}98,28 \\
(2010)\end{array}$ & $-1,00$ & $-1,39 ;-0,60$ & $<0,001$ \\
\hline
\end{tabular}

tymų, raudonukès ir epideminio parotito doze apréptis savivaldybių mastu 2010-2018 metais. Duomenys buvo renkami iš Nacionalinio visuomenès sveikatos centro prie Sveikatos apsaugos ministerijos departamentų teikiamų Imuniteto būklès ataskaitų Nr. 7 - sveikata (metinè), patvirtintų Lietuvos Respublikos sveikatos apsaugos ministro $2005 \mathrm{~m}$. vasario 10 d. ịsakymu Nr. V-109 „Dèl užkrečiamujjų ligų statistinių ataskaitos ir apskaitos formu patvirtinimo“.

Duomenų analizė atlikta WinPepi 11.65 programa, naudotas R programos 3.2.2 paketas. Profilaktinių skiepijimų aprèpties tendencijų Lietuvoje vertinimui pasirinktas Mantel-Haenszel chi kvadrato $\left(\chi^{2}\right)$ testas. Tendencijos laikomos statistiškai reikšmingomis, kai $p \leq 0,05$. Apskaičiuoti skiepijimų aprèpties metiniai vidutiniai procentiniai pokyčiai bei jų 95 proc. pasikliautinieji intervalai.

Esant duomenų atskyrimo savivaldybėse problemai (kai kurių savivaldybių duomenys teikiami bendrai), nebuvo galimybès atskirai apskaičiuoti tendencijų ir metinių vidutinių procentinių pokyčių. Kai kurių savivaldybių duomenys atskirti ir pradèti teikti vèliau, nei nagrinèjamojo laikotarpio pradžioje (pvz., Alytaus miesto ir Alytaus rajono savival-

\begin{tabular}{|c|c|c|c|c|c|}
\hline Klaipėdos r. sav. & $\begin{array}{c}94,38 \\
(2018)\end{array}$ & $\begin{array}{c}97,36 \\
(2010)\end{array}$ & $-0,35$ & $-0,50 ;-0,20$ & 0,004 \\
\hline Kretingos r. sav. & $\begin{array}{c}84,75 \\
(2018)\end{array}$ & $\begin{array}{l}97,35 \\
(2010)\end{array}$ & $-0,88$ & $-1,75 ;-0,01$ & $<0,001$ \\
\hline Palangos m. sav. & $\begin{array}{c}85,23 \\
(2018)\end{array}$ & $\begin{array}{c}95,79 \\
(2010)\end{array}$ & $-1,03$ & $-1,73 ;-0,33$ & $<0,001$ \\
\hline Skuodo r. sav. & $\begin{array}{c}85,40 \\
(2012)\end{array}$ & $\begin{array}{c}98,29 \\
(2015)\end{array}$ & $+0,11$ & $-1,05 ;+1,28$ & 0,936 \\
\hline Šilutès r. sav. & $\begin{array}{c}89,96 \\
(2011)\end{array}$ & $\begin{array}{c}98,51 \\
(2016)\end{array}$ & $+0,47$ & $-0,16 ;+1,09$ & $<0,001$ \\
\hline Šiaulių m. sav. & $\begin{array}{c}91,41 \\
(2014)\end{array}$ & $\begin{array}{c}97,43 \\
(2010)\end{array}$ & $-0,10$ & $-0,63 ;+0,43$ & 0,143 \\
\hline Šiaulių r. sav. & $\begin{array}{c}95,22 \\
(2011)\end{array}$ & $\begin{array}{c}99,56 \\
(2015) \\
\end{array}$ & $+0,35$ & $+0,05 ;+0,64$ & 0,007 \\
\hline Radviliškio r. sav. & $\begin{array}{c}87,92 \\
(2013)\end{array}$ & $\begin{array}{c}99,05 \\
(2017)\end{array}$ & $+1,25$ & $+0,28 ;+2,23$ & $<0,001$ \\
\hline Kelmès r. sav. & $\begin{array}{c}95,50 \\
(2013) \\
\end{array}$ & $\begin{array}{c}99,40 \\
(2017) \\
\end{array}$ & $+0,07$ & $-0,25 ;+0,39$ & 0,710 \\
\hline Joniškio r. sav. & $\begin{array}{c}92,44 \\
(2018)\end{array}$ & $\begin{array}{c}97,89 \\
(2010)\end{array}$ & $-0,28$ & $-0,74 ;+0,19$ & 0,151 \\
\hline Pakruojo r. sav. & $\begin{array}{c}90,91 \\
(2013)\end{array}$ & $\begin{array}{c}98,70 \\
(2016)\end{array}$ & $+0,22$ & $-0,39 ;+0,83$ & 0,320 \\
\hline Akmenės r. sav. & $\begin{array}{c}84,97 \\
(2011)\end{array}$ & $\begin{array}{c}96,70 \\
(2016)\end{array}$ & $+0,89$ & $-0,09 ;+1,87$ & 0,001 \\
\hline Panevėžio m. sav. & $\begin{array}{c}91,55 \\
(2011)\end{array}$ & $\begin{array}{c}96,89 \\
(2016)\end{array}$ & $+0,14$ & $-0,28 ;+0,57$ & 0,130 \\
\hline Panevèžio r. sav. & $\begin{array}{c}91,64 \\
(2014)\end{array}$ & $\begin{array}{c}99,01 \\
(2010)\end{array}$ & $-0,29$ & $-0,83 ;+0,26$ & 0,072 \\
\hline Rokiškio r. sav. & $\begin{array}{c}93,78 \\
(2018) \\
\end{array}$ & $\begin{array}{c}97,71 \\
(2010) \\
\end{array}$ & $-0,21$ & $-0,50 ;+0,07$ & 0,243 \\
\hline Pasvalio r. sav. & $\begin{array}{c}88,16 \\
(2012)\end{array}$ & $\begin{array}{c}98,65 \\
(2018)\end{array}$ & $+0,24$ & $-0,77 ;+1,26$ & 0,362 \\
\hline Biržų r. sav. & $\begin{array}{c}87,63 \\
(2013)\end{array}$ & $\begin{array}{c}99,50 \\
(2014)\end{array}$ & $-0,47$ & $-1,47 ;+0,54$ & 0,011 \\
\hline Kupiškio r. sav. & $\begin{array}{c}89,34 \\
(2015)\end{array}$ & $\begin{array}{c}98,28 \\
(2012)\end{array}$ & $-0,36$ & $-1,05 ;+0,33$ & 0,152 \\
\hline
\end{tabular}


4 lentelè. Skiepijimo MMR1 vakcina aprèpties analizė Marijampolès, Alytaus, Telšių, Utenos ir Tauragès apskričių savivaldybėse 2010-2018 metais*

* Alytaus m. sav., Alytaus $r$. sav., Plungés $r$. sav. ir Rietavo sav. -2014-2018 metais

\begin{tabular}{|c|c|c|c|c|c|}
\hline \multirow[t]{2}{*}{ Savivaldybė } & \multicolumn{2}{|c|}{$\begin{array}{c}\text { Skiepijimo } \\
\text { apréptis (\%), jos } \\
\text { nustatymo metai }\end{array}$} & \multirow{2}{*}{$\begin{array}{c}\text { Metinis } \\
\text { viduti- } \\
\text { nis po- } \\
\text { kytis } \\
(\%)\end{array}$} & \multirow[t]{2}{*}{$95 \%$ PI } & \multirow{2}{*}{$\begin{array}{c}\text { M-H } \\
\mathbf{p}\end{array}$} \\
\hline & $\begin{array}{c}\text { žemiau- } \\
\text { sia }\end{array}$ & $\begin{array}{l}\text { aukš- } \\
\text { čiausia }\end{array}$ & & & \\
\hline $\begin{array}{l}\text { Marijampolès sav., } \\
\text { Kazlu Rūdos sav., } \\
\text { Kalvarijos sav. }\end{array}$ & $\begin{array}{l}92,67 \\
(2012)\end{array}$ & $\begin{array}{l}96,70 \\
(2018)\end{array}$ & $+0,15$ & $-0,16 ;+0,46$ & 0,174 \\
\hline Vilkaviškio r. sav. & $\begin{array}{l}90,13 \\
(2014)\end{array}$ & $\begin{array}{l}96,11 \\
(2011)\end{array}$ & $+0,03$ & $-0,55 ;+0,62$ & 0,859 \\
\hline Šakiu r. sav. & $\begin{array}{l}81,43 \\
(2012) \\
\end{array}$ & $\begin{array}{l}96,22 \\
(2017) \\
\end{array}$ & $+1,02$ & $-0,18 ;+2,22$ & $<0,001$ \\
\hline Alytaus m. sav. * & $\begin{array}{l}95,13 \\
(2017)\end{array}$ & $\begin{array}{l}98,41 \\
(2015)\end{array}$ & $-0,46$ & $-1,30 ;+0,39$ & 0,073 \\
\hline Alytaus r. sav. * & $\begin{array}{l}94,61 \\
(2016)\end{array}$ & $\begin{array}{l}100,00 \\
(2014)\end{array}$ & $-0,77$ & $-2,24 ;+0,71$ & 0,116 \\
\hline Varènos r. sav. & $\begin{array}{c}82,99 \\
(2018)\end{array}$ & $\begin{array}{l}96,91 \\
(2010 \\
2012) \\
\end{array}$ & $-1,27$ & $-2,17 ;-0,36$ & $<0,001$ \\
\hline Druskininkų sav. & $\begin{array}{l}92,70 \\
(2018)\end{array}$ & $\begin{array}{l}100,00 \\
(2012 \\
2015)\end{array}$ & $-0,47$ & $-0,98 ;+0,04$ & $<0,001$ \\
\hline Lazdijų r. sav. & $\begin{array}{l}93,20 \\
(2015)\end{array}$ & $\begin{array}{l}97,74 \\
(2012)\end{array}$ & $-0,28$ & $-0,62 ;+0,06$ & 0,173 \\
\hline Telšių r. sav. & $\begin{array}{l}84,48 \\
(2013)\end{array}$ & $\begin{array}{l}89,77 \\
(2010)\end{array}$ & $+0,07$ & $-0,49 ;+0,64$ & 0,937 \\
\hline Mažeikių r. sav. & $\begin{array}{l}96,04 \\
(2018)\end{array}$ & $\begin{array}{l}98,81 \\
(2017) \\
\end{array}$ & $-0,02$ & $-0,25 ;+0,21$ & 0,975 \\
\hline Plungès r. sav. * & $\begin{array}{l}90,61 \\
(2017)\end{array}$ & $\begin{array}{l}97,21 \\
(2014)\end{array}$ & $-1,63$ & $-3,14 ;-0,09$ & $<0,001$ \\
\hline Rietavo sav. * & $\begin{array}{l}85,25 \\
(2018) \\
\end{array}$ & $\begin{array}{l}98,57 \\
(2017)\end{array}$ & $-1,64$ & $-6,37 ;+3,34$ & 0,197 \\
\hline Utenos r. sav. & $\begin{array}{l}90,64 \\
(2011)\end{array}$ & $\begin{array}{l}95,03 \\
(2018)\end{array}$ & $+0,13$ & $-0,31 ;+0,57$ & 0,571 \\
\hline Anykščių r. sav. & $\begin{array}{l}91,98 \\
(2011)\end{array}$ & $\begin{array}{l}100,00 \\
(2010 \\
2012)\end{array}$ & $+0,20$ & $-0,47 ;+0,87$ & 0,221 \\
\hline Visagino sav. & $\begin{array}{l}87,18 \\
(2015) \\
\end{array}$ & $\begin{array}{l}100,00 \\
(2011) \\
\end{array}$ & $-0,55$ & $-1,74 ;+0,66$ & 0,001 \\
\hline Molètų r. sav. & $\begin{array}{l}89,66 \\
(2013) \\
\end{array}$ & $\begin{array}{l}96,55 \\
(2017) \\
\end{array}$ & $+0,67$ & $+0,11 ;+1,22$ & 0,044 \\
\hline Zarasų r. sav. & $\begin{array}{l}89,74 \\
(2016)\end{array}$ & $\begin{array}{l}95,00 \\
(2013)\end{array}$ & $-0,42$ & $-0,81 ;-0,03$ & 0,212 \\
\hline Ignalinos r. sav. & $\begin{array}{l}94,38 \\
(2017)\end{array}$ & $\begin{array}{c}100,00 \\
(2011- \\
2012) \\
\end{array}$ & $-0,44$ & $-0,77 ;-0,10$ & 0,019 \\
\hline $\begin{array}{l}\text { Tauragès r. sav. } \\
\text { ir Pagègių sav. }\end{array}$ & $\begin{array}{l}89,50 \\
(2013) \\
\end{array}$ & $\begin{array}{l}97,48 \\
(2010) \\
\end{array}$ & $+0,22$ & $-0,47 ;+0,92$ & 0,177 \\
\hline Jurbarko r. sav. & $\begin{array}{l}90,95 \\
(2018) \\
\end{array}$ & $\begin{array}{l}96,67 \\
(2014)\end{array}$ & $+0,05$ & $-0,54 ;+0,64$ & 0,676 \\
\hline Šilalès r. sav. & $\begin{array}{l}82,49 \\
(2010)\end{array}$ & $\begin{array}{l}95,22 \\
(2016)\end{array}$ & $+1,45$ & $\begin{array}{c}+0,57 \\
+2,33 \\
\end{array}$ & $<0,001$ \\
\hline
\end{tabular}

dybių duomenys atskirti 2014-aisiais metais), todèl tokiais atvejais skaičiuotos trumpesnio laikotarpio tendencijos ir metiniai vidutiniai procentiniai pokyčiai.
5 lentelè. Skiepijimo MMR2 vakcina aprèpties analizė Vilniaus, Kauno, Klaipėdos ir Šiaulių apskričių savivaldybėse 2010-2018 metais*

* Prienų r. sav. ir Birštono sav. - 2013-2018 metais

** Pakruojo $r$. sav. - 2012-2018 metais

\begin{tabular}{|c|c|c|c|c|c|}
\hline \multirow[t]{2}{*}{ Savivaldybė } & \multicolumn{2}{|c|}{$\begin{array}{c}\begin{array}{c}\text { Skiepijimo aprèptis } \\
(\%),\end{array} \\
\text { jos nustatymo metai }\end{array}$} & \multirow{2}{*}{\begin{tabular}{|c|} 
Metinis \\
vidu- \\
tinis \\
pokytis \\
$(\%)$ \\
\end{tabular}} & \multirow[t]{2}{*}{$95 \%$ PI } & \multirow{2}{*}{$\begin{array}{c}\text { M-H } \\
\mathbf{p}\end{array}$} \\
\hline & \begin{tabular}{|c|}
$\begin{array}{c}\text { žemiau- } \\
\text { sia }\end{array}$ \\
\end{tabular} & $\begin{array}{c}\text { aukš- } \\
\text { čiausia }\end{array}$ & & & \\
\hline Vilniaus m. sav. & \begin{tabular}{|c|}
89,61 \\
$(2014 ;$ \\
$2016)$ \\
\end{tabular} & $\begin{array}{c}96,49 \\
(2010)\end{array}$ & $-0,69$ & $-1,19 ;-0,18$ & $<0,001$ \\
\hline Vilniaus r. sav. & $\begin{array}{l}94,97 \\
(2015)\end{array}$ & $\begin{array}{l}98,98 \\
(2010) \\
\end{array}$ & $-0,42$ & $-0,60 ;-0,25$ & $<0,001$ \\
\hline $\begin{array}{l}\text { Trakų r. sav. ir } \\
\text { Elektrènų sav. }\end{array}$ & $\begin{array}{l}86,48 \\
(2010)\end{array}$ & $\begin{array}{l}95,68 \\
(2018)\end{array}$ & $+0,82$ & $+0,15 ;+1,50$ & $<0,001$ \\
\hline Šalčininkų r. sav. & $\begin{array}{l}96,42 \\
(2013)\end{array}$ & $\begin{array}{l}100,00 \\
(2012)\end{array}$ & $-0,15$ & $-0,45 ;+0,15$ & 0,104 \\
\hline Švenčionių r. sav. & $\begin{array}{l}95,54 \\
(2010)\end{array}$ & $\begin{array}{c}98,81 \\
(2018) \\
\end{array}$ & $+0,07$ & $-0,24 ;+0,37$ & 0,730 \\
\hline Ukmergès r. sav. & $\begin{array}{l}91,88 \\
(2011)\end{array}$ & $\begin{array}{l}96,99 \\
(2016)\end{array}$ & $+0,30$ & $-0,17 ;+0,77$ & 0,058 \\
\hline Širvintų r. sav. & $\begin{array}{l}90,98 \\
(2018)\end{array}$ & $\begin{array}{l}98,51 \\
(2011)\end{array}$ & $-0,54$ & $-1,00 ;-0,09$ & 0,020 \\
\hline Kauno m. sav. & $\begin{array}{l}90,95 \\
(2015) \\
\end{array}$ & $\begin{array}{l}94,31 \\
(2011) \\
\end{array}$ & $-0,32$ & $-0,57 ;-0,07$ & $<0,001$ \\
\hline Kauno r. sav. & $\begin{array}{l}93,04 \\
(2014)\end{array}$ & $\begin{array}{c}97,33 \\
(2010) \\
\end{array}$ & $-0,35$ & $-0,66 ;-0,04$ & 0,003 \\
\hline Raseinių r. sav. & $\begin{array}{l}93,04 \\
(2014)\end{array}$ & $\begin{array}{l}99,67 \\
(2015)\end{array}$ & $+0,03$ & $-0,47 ;+0,53$ & 0,954 \\
\hline Kaišiadorių r. sav. & $\begin{array}{l}81,06 \\
(2012)\end{array}$ & $\begin{array}{c}97,52 \\
(2013)\end{array}$ & $+0,25$ & $-1,25 ;+1,78$ & 0,151 \\
\hline Kèdainių r. sav. & $\begin{array}{l}87,00 \\
(2017)\end{array}$ & $\begin{array}{c}97,23 \\
(2011)\end{array}$ & $-0,68$ & $-1,35 ;-0,01$ & $<0,001$ \\
\hline Prienų r. sav. * & $\begin{array}{l}89,80 \\
(2015)\end{array}$ & $\begin{array}{c}96,31 \\
(2014)\end{array}$ & $-0,57$ & $-1,89 ;+0,77$ & 0,128 \\
\hline Jonavos r. sav. & $\begin{array}{l}90,68 \\
(2018)\end{array}$ & $\begin{array}{l}98,06 \\
(2016)\end{array}$ & $-0,51$ & $-1,14 ;+0,14$ & $<0,001$ \\
\hline Birštono sav. * & $\begin{array}{l}70,00 \\
(2015)\end{array}$ & $\begin{array}{l}95,00 \\
(2017)\end{array}$ & $+1,99$ & $-4,01 ;+8,35$ & 0,451 \\
\hline $\begin{array}{l}\text { Klaipėdos m. sav. } \\
\text { ir Neringos sav. }\end{array}$ & $\begin{array}{l}90,37 \\
(2018)\end{array}$ & $\begin{array}{c}98,81 \\
(2010) \\
\end{array}$ & $-0,87$ & $-1,21 ;-0,53$ & $<0,001$ \\
\hline Klaipėdos r. sav. & $\begin{array}{l}93,30 \\
(2016) \\
\end{array}$ & $\begin{array}{c}97,91 \\
(2010)\end{array}$ & $-0,32$ & $-0,61 ;-0,04$ & 0,009 \\
\hline Kretingos r. sav. & $\begin{array}{l}94,42 \\
(2018)\end{array}$ & $\begin{array}{c}98,55 \\
(2011)\end{array}$ & $-0,47$ & $-0,63 ;-0,30$ & $<0,001$ \\
\hline Palangos m. sav. & $\begin{array}{l}94,74 \\
(2016 \\
2017)\end{array}$ & $\begin{array}{l}98,53 \\
(2010)\end{array}$ & $-0,22$ & $-0,58 ;+0,14$ & 0,303 \\
\hline Skuodo r. sav. & $\begin{array}{l}91,04 \\
(2018)\end{array}$ & $\begin{array}{c}98,21 \\
(2012)\end{array}$ & $-0,64$ & $-1,09 ;-0,19$ & 0,006 \\
\hline Šilutės r. sav. & $\begin{array}{l}92,45 \\
(2011)\end{array}$ & $\begin{array}{l}99,32 \\
(2014)\end{array}$ & $+0,55$ & $+0,07 ;+1,03$ & $<0,001$ \\
\hline Šiaulių m. sav. & $\begin{array}{l}91,94 \\
(2014)\end{array}$ & $\begin{array}{c}98,53 \\
(2010)\end{array}$ & $-0,17$ & $-0,68 ;+0,34$ & 0,022 \\
\hline Šiaulių r. sav. & $\begin{array}{l}98,29 \\
(2010)\end{array}$ & $\begin{array}{l}100,00 \\
(2011- \\
2013 ; \\
2015 ; \\
2017) \\
\end{array}$ & $+0,08$ & $-0,07 ;+0,22$ & 0,111 \\
\hline Radviliškio r. sav. & $\begin{array}{l}94,83 \\
(2012) \\
\end{array}$ & $\begin{array}{l}100,00 \\
(2011)\end{array}$ & $+0,11$ & $-0,39 ;+0,62$ & 0,222 \\
\hline
\end{tabular}




\begin{tabular}{|c|c|c|c|c|c|}
\hline Kelmės r. sav. & \begin{tabular}{|l}
95,73 \\
$(2018)$ \\
\end{tabular} & $\begin{array}{l}99,67 \\
(2011) \\
\end{array}$ & $-0,28$ & $-0,54 ;-0,02$ & 0,003 \\
\hline Jon & $\begin{array}{l}95,96 \\
(2017)\end{array}$ & $\begin{array}{l}99,43 \\
(2018)\end{array}$ & $+0,03$ & $\begin{array}{l}-0,26 \\
+0,32\end{array}$ & 0,927 \\
\hline $\begin{array}{l}\text { Pakruojo r. } \\
\text { sav.* }\end{array}$ & $\begin{array}{l}95,92 \\
(2017)\end{array}$ & $\begin{array}{l}99,50 \\
(2013)\end{array}$ & $-0,30$ & $\begin{array}{l}-0,69 \\
+0,10\end{array}$ & 0,153 \\
\hline $\begin{array}{l}\text { Akmenès } r \text {. } \\
\text { sav. }\end{array}$ & $\begin{array}{l}94,06 \\
(2011)\end{array}$ & $\begin{array}{l}99,51 \\
(2012)\end{array}$ & $-0,02$ & $\begin{array}{l}-0,57 \\
+0,54\end{array}$ & 0,855 \\
\hline
\end{tabular}

6 lentelè. Skiepijimo MMR2 vakcina aprèpties analizė Panevėžio, Marijampolès, Alytaus, Telšių, Utenos ir Tauragès apskričių savivaldybėse 2010-2018 metais*

* Alytaus m. sav., Alytaus r. sav., Plungés $r$. sav. ir Rietavo sav. -2014-2018 metais, ** Ignalinos r. sav. - 2011-2018 metais

\begin{tabular}{|c|c|c|c|c|c|}
\hline \multirow[t]{2}{*}{ Savivaldybė } & \multicolumn{2}{|c|}{$\begin{array}{c}\text { Skiepijimo } \\
\text { aprèptis (\%), } \\
\text { jos nustatymo } \\
\text { metai }\end{array}$} & \multirow{2}{*}{$\begin{array}{c}\text { Metinis } \\
\text { vidu- } \\
\text { tinis } \\
\text { pokytis } \\
(\%)\end{array}$} & \multirow[t]{2}{*}{$95 \%$ PI } & \multirow[t]{2}{*}{$\begin{array}{c}\text { M-H } \\
\text { p }\end{array}$} \\
\hline & \begin{tabular}{|c|}
$\begin{array}{c}\text { žemiau- } \\
\text { sia }\end{array}$ \\
\end{tabular} & \begin{tabular}{|c|} 
aukš- \\
čiausia
\end{tabular} & & & \\
\hline Panevėžio m. sav. & $\begin{array}{l}93,15 \\
(2015) \\
\end{array}$ & \begin{tabular}{|c|}
97,91 \\
$(2017)$ \\
\end{tabular} & $+0,19$ & $-0,23 ;+0,62$ & 0,011 \\
\hline Panevėžio r. sav. & $\begin{array}{c}93,37 \\
(2014)\end{array}$ & $\begin{array}{c}99,49 \\
(2010)\end{array}$ & $-0,27$ & $-0,76 ;+0,22$ & 0,025 \\
\hline Rokiškio r. sav. & $\begin{array}{l}94,72 \\
(2013)\end{array}$ & $\begin{array}{c}99,65 \\
(2012) \\
\end{array}$ & $-0,07$ & $-0,48 ;+0,33$ & 0,402 \\
\hline Pasvalio r. sav. & $\begin{array}{l}77,74 \\
(2015)\end{array}$ & $\begin{array}{c}99,62 \\
(2018) \\
\end{array}$ & $-0,40$ & $-2,68 ;+1,92$ & 0,026 \\
\hline Biržų r. sav. & $\begin{array}{l}94,12 \\
(2013)\end{array}$ & $\begin{array}{l}100,00 \\
(2010) \\
\end{array}$ & $-0,29$ & $-0,70 ;+0,12$ & 0,008 \\
\hline Kupiškio r. sav. & $\begin{array}{l}98,16 \\
(2011)\end{array}$ & $\begin{array}{l}100,00 \\
(2014 ; \\
2016- \\
2018) \\
\end{array}$ & $+0,29$ & $+0,17 ;+0,40$ & 0,006 \\
\hline $\begin{array}{l}\text { Marijampolès sav., } \\
\text { Kazlų Rūdos sav., } \\
\text { Kalvarijos sav. }\end{array}$ & $\begin{array}{c}94,64 \\
(2014)\end{array}$ & $\begin{array}{c}98,24 \\
(2011)\end{array}$ & $-0,20$ & $-0,49 ;+0,09$ & 0,009 \\
\hline Vilkaviškio r. sav. & $\begin{array}{l}94,48 \\
(2010) \\
\end{array}$ & \begin{tabular}{|c|}
98,04 \\
$(2014)$ \\
\end{tabular} & $+0,09$ & $-0,22 ;+0,41$ & 0,342 \\
\hline Šakių r. sav. & $\begin{array}{l}91,32 \\
(2016) \\
\end{array}$ & $\begin{array}{c}99,40 \\
(2011) \\
\end{array}$ & $-0,51$ & $-1,11 ;+0,09$ & 0,004 \\
\hline Alytaus m. sav. * & $\begin{array}{l}98,11 \\
(2018) \\
\end{array}$ & \begin{tabular}{|c|}
99,64 \\
$(2015)$ \\
\end{tabular} & $-0,25$ & $-0,66 ;+0,16$ & 0,114 \\
\hline Alytaus r. sav. * & $\begin{array}{l}95,24 \\
(2016) \\
\end{array}$ & \begin{tabular}{|c|}
99,38 \\
$(2014)$ \\
\end{tabular} & $-0,30$ & $-1,58 ;+0,99$ & 0,554 \\
\hline Varėnos r. sav. & $\begin{array}{l}95,24 \\
(2018)\end{array}$ & $\begin{array}{l}100,00 \\
(2010)\end{array}$ & $-0,60$ & $-0,77 ;-0,43$ & $<0,001$ \\
\hline Druskininkų sav. & $\begin{array}{l}98,45 \\
(2018)\end{array}$ & \begin{tabular}{|c|}
100,00 \\
$(2010-$ \\
$2017)$ \\
\end{tabular} & $-0,10$ & $-0,22 ;+0,01$ & 0,006 \\
\hline Lazdijų r. sav. & $\begin{array}{l}95,93 \\
(2010) \\
\end{array}$ & \begin{tabular}{|c|}
99,30 \\
$(2018)$ \\
\end{tabular} & $+0,16$ & $-0,14 ;+0,46$ & 0,333 \\
\hline Telšių r. sav. & $\begin{array}{l}84,63 \\
(2013) \\
\end{array}$ & \begin{tabular}{|c|}
91,50 \\
$(2018)$ \\
\end{tabular} & $+0,30$ & $-0,26 ;+0,87$ & 0,213 \\
\hline Mažeikių r. sav. & $\begin{array}{c}97,29 \\
(2018)\end{array}$ & $\begin{array}{c}99,19 \\
(2017)\end{array}$ & $-0,07$ & $-0,22 ;+0,08$ & 0,276 \\
\hline Plungès r. sav. * & $\begin{array}{l}98,79 \\
(2018)\end{array}$ & $\begin{array}{l}100,00 \\
(2015) \\
\end{array}$ & $-0,27$ & $-0,45 ;-0,10$ & 0,023 \\
\hline Rietavo sav. * & $\begin{array}{l}95,31 \\
(2014)\end{array}$ & $\begin{array}{l}100,00 \\
(2016)\end{array}$ & $+0,30$ & $-1,25 ;+1,88$ & 0,681 \\
\hline
\end{tabular}

\begin{tabular}{|l|c|c|c|c|c|}
\hline Utenos r. sav. & $\begin{array}{c}93,73 \\
(2016)\end{array}$ & $\begin{array}{c}97,13 \\
(2014)\end{array}$ & $-0,08$ & $-0,40 ;+0,24$ & 0,616 \\
\hline Anykščiu r. sav. & $\begin{array}{c}97,00 \\
(2011)\end{array}$ & $\begin{array}{c}100,00 \\
(2010 ; \\
2012- \\
2017)\end{array}$ & $+0,11$ & $-0,14 ;+0,37$ & 0,083 \\
\hline Visagino sav. & $\begin{array}{c}86,93 \\
(2013)\end{array}$ & $\begin{array}{c}100,00 \\
(2010- \\
2011)\end{array}$ & $-0,70$ & $-2,00 ;+0,61$ & 0,001 \\
\hline Molètų r. sav. & $\begin{array}{c}92,90 \\
(2013)\end{array}$ & $\begin{array}{c}98,50 \\
(2018)\end{array}$ & $+0,84$ & $+0,50 ;+1,18$ & $<0,001$ \\
\hline Zarasų r. sav. & $\begin{array}{c}80,98 \\
(2016)\end{array}$ & $\begin{array}{c}98,40 \\
(2017)\end{array}$ & $-0,43$ & $-1,91 ;+1,07$ & 0,053 \\
\hline Ignalinos r. sav. ** & $\begin{array}{c}90,83 \\
(2016)\end{array}$ & $\begin{array}{c}100,00 \\
(2012)\end{array}$ & $-0,47$ & $-1,35 ;+0,41$ & 0,020 \\
\hline $\begin{array}{l}\text { Tauragės r. sav. } \\
\text { ir Pagègių sav. }\end{array}$ & $\begin{array}{c}91,08 \\
(2015)\end{array}$ & $\begin{array}{c}100,00 \\
(2011)\end{array}$ & $-0,56$ & $-1,20 ;+0,07$ & $<0,001$ \\
\hline Jurbarko r. sav. & $\begin{array}{c}96,39 \\
(2018)\end{array}$ & $\begin{array}{c}100,00 \\
(2010)\end{array}$ & $-0,15$ & $-0,43 ;+0,12$ & 0,261 \\
\hline Šilalės r. sav. & $\begin{array}{c}81,85 \\
(2012)\end{array}$ & $\begin{array}{c}96,09 \\
(2015)\end{array}$ & $+1,19$ & $-0,18 ;+2,59$ & $<0,001$ \\
\hline
\end{tabular}

\section{Tyrimo rezultatai ir jų aptarimas}

Išanalizavus 2 metų vaikų skiepijimo MMR1 vakcina, o 8 metų vaikų - MMR2 vakcina aprèptị (iki 89,99 proc.; nuo 90 proc.; nuo 95 proc.) savivaldybėse ir palyginus ją su rekomenduojama skiepijimų apréptimi nustatyta, kad 2 ir 8 metų vaikų skiepijimo atitinkamomis vakcinomis rekomenduojamai 95 proc. ir didesnei aprépčiai Lietuvos savivaldybèse būdinga mažejimo tendencija. Kitiems aprépties mastams (iki 89,99 proc.; nuo 90 proc.) nustatyta didejjimo tendencija ( 1,2 lentelès).

Ivertinus 2 metų vaikų skiepijimo MMR1 vakcina, o 8 metu vaiku - MMR2 vakcina apreptis 2010-2018 metais savivaldybėse, nustatyta, kad skiepijimų MMR1 vakcina mažèjimo tendencija stebima 35 savivaldybèse (3, 4 lentelès), o MMR2 - 40 (5, 6 lentelès). Skiepijimo MMR1 vakcina atveju didžiausias statistiškai reikšmingas $(95 \%$ PI: $-3,14 \% ;-0,09 \%)$ neigiamas metinis vidutinis procentinis pokytis $(-1,63 \%)$ nustatytas Plungès rajono savivaldybeje (4 lentelè), o MMR2 - Klaipèdos miesto ir Neringos savivaldybėse (-0,87\%) (95\% PI: -1,21\%; -0,53\%) (5 lentelè). 2 metų vaikų skiepijimo MMR1 vakcina aprèpties didžiausias statistiškai reikšmingas ( $95 \%$ PI: $+0,57 \% ;+2,33 \%$ ) teigiamas metinis vidutinis procentinis pokytis $(+1,45 \%)$ nustatytas Šilalès rajono savivaldybèje (4 lentelè), o 8 metu vaikų skiepijimo MMR2 vakcina aprèpties - Molètų rajono savivaldybejje $(+0,84 \%)(95 \%$ PI: $+0,50 \% ;+1,18 \%)(6$ lentelè).

\section{Išvados}

1. Nagrinejjamuoju laikotarpiu profilaktinių skiepijimų nuo tymų, raudonukès ir epideminio parotito aprèpčiai daugumoje Lietuvos savivaldybių būdinga mažejimo tendencija. 
2. Nustatytos Lietuvos savivaldybių, atitinkančių rekomenduojamą skiepijimo nuo tymų, raudonukès ir epideminio parotito ( $\geq 95 \%$ ) aprèptį, skaičiaus mažèjimo tendencijos. Mažesnè nei rekomenduojama skiepijimo aprèptis sudaro prielaidas užkrečiamujų ligų protrūkiams.

3. Darbo rezultatai atskleidè didelius netolygumus, igyvendinant vaikų profilaktinị skiepijimą analizuojamuoju laikotarpiu. Skiepijimo aprèpties kitimo tendencijos savivaldybėse skirtingos. Nevienodas asmens ir visuomenès sveikatos priežiūros specialistų požiūris, jų darbo organizavimas skirtingose teritorijose gali būti laikomas skiepijimo aprèpties netolygumų prielaida.

\section{Literatūra}

1. Succi RCM. Vaccine refusal - what we need to know. J Pediatr 2018;94(6):574-581.

https://doi.org/10.1016/j.jped.2018.01.008

2. Bozzola E, Spina G, Russo R, Bozzola M, Corsello G, Vilanni A. Mandatory vaccinations in European countries, undocumented information, false news and the impact on vaccination uptake: the position of the Italian pediatric society. Ital J Pediatr 2018;44:67. https://doi.org/10.1186/s13052-018-0504-y

3. Costa-Pinto JC, Willaby HW, Leask J, Hoq M, Schuster T, Ghazarian A, O'Keefe J, Danchin MH. Parental immunisation needs and attitudes survey in paediatric hospital clinics and community maternal and child health centres in Melbourne, Australia. J Paediatr Child Health 2018;54(5):522-529.

https://doi.org/10.1111/jpc.13790

4. Brunson EK. How parents make decisions about their children's vaccinations. Vaccine 2013;31(46):5466-5470.

https://doi.org/10.1016/j.vaccine.2013.08.104

5. Lietuvos Respublikos sveikatos apsaugos ministro $2019 \mathrm{~m}$. sausio 28 d. ịsakymas Nr. V-115 "Dèl Nacionalinès imunoprofilaktikos 2019-2023 metų programos patvirtinimo".

6. Vannice KS, Salmon DA, Shui I, Omer SB, Kissner J, Edwards KM, Sparks R, Dekker CL, Klein NP, Gust DA. Attitudes and beliefs of parents concerned about vaccines: impact of timing of immunization information. Pediatrics 2011;127(1):120-126. https://doi.org/10.1542/peds.2010-1722R
7. Holt E. 41000 measles cases in Europe since the beginning of 2018. Lancet 2018;392(10149):724.

https://doi.org/10.1016/S0140-6736(18)32031-2

\section{REVIEW OF THE MEASLES, MUMPS AND RUBELLA VACCINATION COVERAGE IN \\ THE MUNICIPALITIES OF LITHUANIA IN 2010-2018}

\section{G. M. Gulbinovič, N. Kuprevičienė}

Keywords: routine immunization, immunization schedule, vaccination coverage, measles, mumps and rubella vaccine, MMR vaccine.

Summary

Inadequate immunization coverage may lead to outbreaks of communicable diseases, including forgotten by public and rare ones. Monitoring vaccination coverage provides an opportunity to strengthen epidemiological surveillance and control of vaccinepreventable diseases.

Aim - to assess measles, mumps and rubella immunization coverage in the municipalities of Lithuania in 2010-2018.

Methods. Descriptive study has been performed by analyzing data on immunization coverage in 2010-2018 from Center for Communicable Diseases and AIDS. WinPepi version 11.65 and $\mathrm{R}$ version 3.2.2 package have been used. Mantel-Haenszel $\chi^{2}$ test has been chosen for statistical hypothesis testing. Results are statistically significant if $\mathrm{p} \leq 0.05$.

Results. The decreasing tendency of measles, mumps and rubella vaccination coverage (first and second doses) of children is common in the majority of municipalities.

Conclusions. The trends of immunization coverage varies depending on municipalities. Unequal approach of personal and public health care specialists, organisation of their work in different territories could be considered as the cause of inequalities in immunization coverage.

Correspondence to: gabrielia.gulbinovic@gmail.com

Gauta 2019-11-15 